\title{
垔硫酸塩の存在下における銀イオンによるチオ硫酸イオン の電位差滴定
}

\author{
池田早苗，侉竹 弘*
}

(1975 年 11 月 7 日受理)

\begin{abstract}
チオ硫酸イオンを直接銀イオンで電位差滴定するオ法を提案する．硫化銀の生成によって終点を求め る方法で，銀イオン選択電極を指示電極として用いた，定量に必要な条件として，滴定温度，pH 及び 亜硫酸イオンの影響などを検討し，チ才硫酸ナトリウム溶液の標定法と巠硫酸ナトリウム中のチオ硫酸 ナトリウムの定量法を確立した。この方法によって (0.0005〜0.005) M チ才硫酸ナトリウム溶液が 0.2 \%以内の相対誤差と変動係数で定量された。 又, 多量の亜硫酸ナトリウムが共存する場合には, 希硫酸 で溶液の $\mathrm{pH}$ を 1.5〜2.0 とし，約 $60^{\circ} \mathrm{C}$ で滴定することによって，ほとえどその影響なくチオ硫酸 イオンを定量できることが明らかになった。

本法は操作が簡単で迅速，かつ精度がよく，亜硫酸イオンの影曏なくチオ硫酸イオンを分析できるの で，通常のヨウ素滴定法より便利と考元られる.
\end{abstract}

\section{1 緒言}

チオ硫酸イオンと銀イオンとの反応怙くから知られ ており，Muller1) は銀イオン溶液にチオ硫酸イオンを添 加する場合には鋭い電位変化が起こるが，その逆の場合 には非常に小さな電位変化しか起こらなかったと報告し

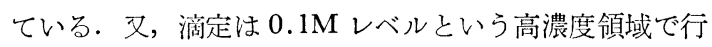
われ，かなり正確な結果が得られているが，定量方法と しては研究されていない. Humphrey ら²)は少量の銀イ オンをチオ硫酸ナトリウムで銀電極とSGE 用いて正 確に電位差滴定する方法を研究しているが, 銀イオンで チオ硫酸イオンを電位差滴定する場合の滴定曲線は再現 性が悪く, 㐫まり有用とは思えないとして詳細な検討は していない。一方 Schmidt と Pungor ${ }^{3)}$ 硫化物イオン 電極を用いる電位差滴定法によって硫化物イオンの銀滴 定を行い，チオ硫酸イオンの影響を検討しているが，チ オ硫酸イオンを銀滴定する方法は報告していない. 又, Bodnar(4) はチオ硫酸イオンに過剩の銀イオンを反応させ (1)，(2)，生成する水素イオンを水酸化ナトリウムで滴 定しているが，これ性銀滴定法ではない。

$$
\begin{aligned}
& \mathrm{S}_{2} \mathrm{O}_{3}{ }^{2-}+2 \mathrm{Ag}^{+} \rightarrow \mathrm{Ag}_{2} \mathrm{~S}_{2} \mathrm{O}_{3} \ldots \ldots \ldots \ldots \ldots . . \\
& \mathrm{Ag}_{2} \mathrm{~S}_{2} \mathrm{O}_{3}+\mathrm{H}_{2} \mathrm{O} \rightarrow \mathrm{Ag}_{2} \mathrm{~S}+\mathrm{SO}_{4}{ }^{2-}+2 \mathrm{H}^{+}
\end{aligned}
$$

著者らは，先に銀線から作った硫化銀電極及びヨウ化

* 徳帛大学工学部: 徳島県德島市南常三島町 2
銀電極を指示電極とする電位差滴定法によって, 硫化物 イオン, チオ硫酸イオン及び西硫酸イオンの 3 成分混合 系の各イオンを逐次示差的に 銀瀜定できる 方法を報告 し5)，チオ硫酸イオンの銀滴定法が微量分析法として有 用であることを示唆した。ここでは市販の銀イオン選択 電極を指示電極として用い，硫化銀生成反応に基ら゙く， チオ硫酸イオンの電位差滴定法について検討した.

更に，多量の亜硫酸イオンと其存寸るチオ硫酸イオン の定量条件について検討を加兄, この方法がヨウ素滴定 法よりも選択性のある簡易微量分析法として有用である ことを明らかにした。

\section{2 試薬，装置及び实験方法}

\section{1 試 薬}

チオ硫酸ナトリウム溶液: 試薬特級品を再蒸留水に溶 解して $0.05 \mathrm{M}$ 溶液を調製し, ヨウ素滴定法により標定 したものを必要に応じて希釈して用いた。

硝酸銀標準溶液：試薬特級品で $0.1 \mathrm{M}$ 溶液を阙製し, 電流滴定法6)で標定したものを適時希釈して用いた。 その他の試薬：すべて試薬特級品を使用した。

\section{2 装 置}

電位差滴定装置は平沼産業自動記録滴定装置 RAT 101 型及び日立堀場 $\mathrm{pH}$ メーター M 7 型を使用した。

指示電極として Orion 銀イオン選択電極 94-16 型炎 用い，SCE と組み合わせて電位差を測定記録した。 
加温装置としては柴田マグネディックスターラー M II 型を利用し，スライダックで $\pm 1{ }^{\circ} \mathrm{C}$ に調節した。

\section{3 実験方法}

$200 \mathrm{ml}$ のか一色ビーカー（滴定セル）に一定濃度の チオ硫酸ナトリウム溶液 $10 \mathrm{ml}$ 它正確に量りとり，水で 全量を $100 \mathrm{ml}$ とした後銀イオン選択電極と SCE を用 い硄酸銀標準溶液で雷位差滴定を行う。

\section{3 实験結果及び考察}

\section{1 チオ硫酸イオンの電位差滴定曲線}

$0.0005 \mathrm{M}$ チオ硫酸ナトリウム溶液 $100 \mathrm{ml} 0.1 \mathrm{M}$ 硄酸銀標準溶液で $20^{\circ} \mathrm{C}$ において電位差滴定したところ Fig. 1 のような洞定曲線が得られた.

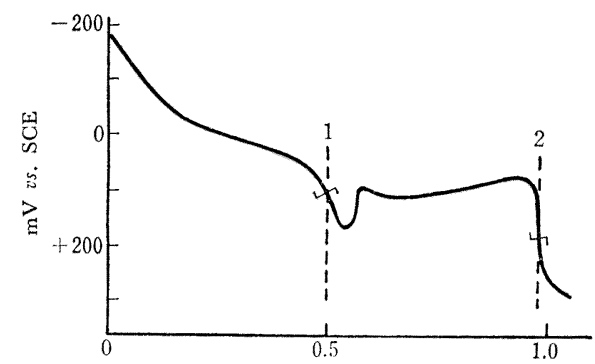

$0.1 \mathrm{M} \mathrm{AgNO}_{3}, \mathrm{ml}$

Fig. 1 Potentiometric titration curve for thiosulfate $0.0005 \mathrm{M} \mathrm{Na}_{2} \mathrm{~S}_{2} \mathrm{O}_{3}: 100 \mathrm{ml}$, at $20^{\circ} \mathrm{C} ; \quad 1$ : First equivalence point; 2 : Second equivalence point

Fig. 1 から明らかなように，二つの明確な電位急变点 が認められる. 最初の電位急变点はチオ硫酸イオンと銀 イオンが 1:1 の結合をしてチオスルフォート銀錯イオ ン它生成することに対応し, 最後の電位急变点はチオ硫 酸イオンと銀イオンが 1:2 の結合をして硫化銀を生成 することに対応するものと考えられる.

\section{2 滴定曲線に対する温度の影響}

被滴定溶液の温度と滴定曲線の形状の関係を調べたと ころ，15ㄷ C下で銀滴定した場合には Fig. 1 における 最初の電位変化が比較的大きくなる反面, 最後の電位変 化が小さく不安定になることが分かった：これは低温で は上記錯イオンが安定化し，硫化銀の生成が遅れるもの と考えられる. しかし，(20〜65) ${ }^{\circ} \mathrm{C}$ で滴定した場合に は, 温度が高くなるにつれて最初の電位変化が小さく不 安定になるとともに，最後の電位変化が大きくなる傾向 が琹められた。古なわち高温では平衡の移動が速くな
り，硫化銀の生成が容易になるものと若えられる，往っ て，最後の電位急变点（硫化銀生成）を終点にする場合 には，被滴定溶液の温度艺 $20^{\circ} \mathrm{C}$ 以上にして滴定するの がよいと結論される。

\section{3 チオ硫酸イオンの分析値に対する pH の影響}

$0.0005 \mathrm{M}$ チオ硫酸ナトリウム溶液 $100 \mathrm{ml}$ を用い, 希 硫酸又は水酸化ナトリウム溶液で各 $\mathrm{pH}$ に調節した溶液

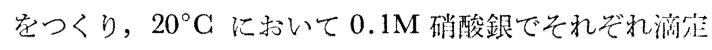
した結果走示すと Fig. 2 のようになる.

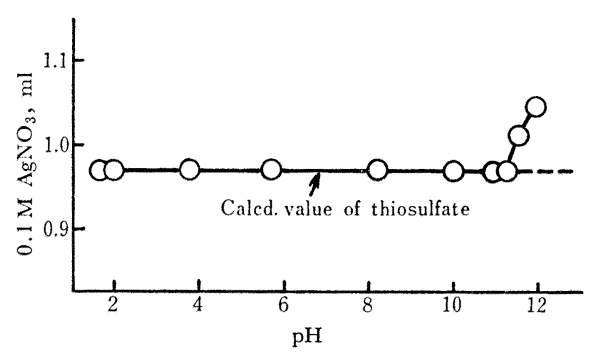

Fig. 2 Effect of $\mathrm{pH}$ on the determination of thiosulfate

$0.0005 \mathrm{M} \mathrm{Na}_{2} \mathrm{~S}_{2} \mathrm{O}_{3}: 100 \mathrm{ml}$

Fig. 2 より，pH 1.5〜10.5 の広い領域にわたって一 定の正確な分析值が得られることが明らかになった。

\section{4 除酸素の効果}

$0.000005 \mathrm{M}$ 程度の特に希薄なチオ硫酸イオン溶液を 滴定すると, 滴定曲線が不安定で終点の電位変化も小さ く，滴定值に大きな正の誤差を与えたが，溶存酸素の影 響と考えられるので，除酸素の効果について検討した. 上記の被滴定溶液に 窒素ガスを 15 分間通気した後, $0.001 \mathrm{M}$ 硝酸銀で滴定すると滴定曲線が安定して, 終点 における電位変化も大きくなり終点も計算值に近くなる ことが分かった，窒素ガスを通気した場合と通気しない 場合の滴定曲線を比較のために示すと Fig. 3 のように なる。

\section{5 チオ硫酸イオン濃度と滴定精度}

(0.000005〜0.005) M チオ硫酸ナトリウム溶液 $100 \mathrm{ml}$ を, $\mathrm{pH}$ 約 5.3 , 温度 $(20 \sim 25)^{\circ} \mathrm{G}$, 滴定時間 $(10 \sim 20)$ 分の条件で, $(0.001 \sim 0.1) \mathrm{M}$ 硝酸銀標準溶液で 滴定し たところ Table 1 のような結果が得られた.

すなわら，(0.00005〜0.005) M チ才硫酸イオンの場 合には $\pm 0.2 \%$ の相対䛊差と $0.4 \%$ 以内の变動係数で 


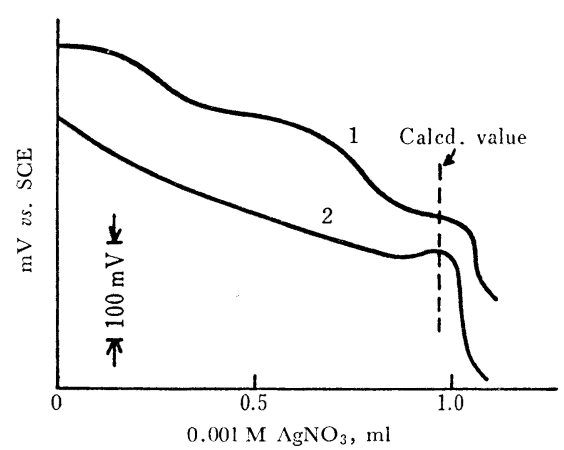

Fig. 3 Effect of deaeration on the titration curve of thiosulfate

$0.000005 \mathrm{M} \mathrm{Na}_{2} \mathrm{~S}_{2} \mathrm{O}_{3}: 100 \mathrm{ml} ; 1:$ Without deaeration; 2 : Deaeration with $\mathrm{N}_{2}$ bubbling

Table 1 Argentometric titration of thiosulfate

\begin{tabular}{llccc}
\hline \multicolumn{2}{c}{ Concentration (M) } & $\begin{array}{c}\text { Relative } \\
\text { error } \\
\mathrm{S}_{2} \mathrm{O}_{3}{ }^{2-}\end{array}$ & $\begin{array}{c}\text { Coefficient } \\
\text { of variation } \\
(\%)\end{array}$ & $\begin{array}{c}\text { Titration } \\
\text { time } \\
(\mathrm{min})\end{array}$ \\
\hline 0.005 & 0.1 & +0.2 & 0.1 & 20 \\
0.0005 & 0.1 & +0.2 & 0.2 & 10 \\
0.00005 & 0.01 & -0.2 & 0.4 & 12 \\
$0.000005 \dagger \dagger$ & 0.001 & +3.6 & 1.0 & 15 \\
\hline
\end{tabular}

Total volume : $100 \mathrm{ml}$; † Average of 5 titrations; $†$ Deaeration with $\mathrm{N}_{2}$ for $15 \mathrm{~min}$

精度よく定量でき， $0.000005 \mathrm{M}$ の場合でも空素ガスを 通じた後滴定すればかなりの精度で定量できることが明 らかになった。

\section{6 亜硫酸イオンと共存するチオ硫酸イオンの定量 \\ 3.6・1 滴定曲線に対する $\mathbf{p H}$ の影響兮硫酸ナ} トリウムにつき $0.0005 \mathrm{M}$ の溶液 $100 \mathrm{ml}$ に, $0.1 \mathrm{M}$ に なるよう业硫酸ナトリウムを共存させ（200 倍モルにな る)，流動パラフィンで液面をおおった後 $0.5 \mathrm{M}$ 硫酸で 各 $\mathrm{pH}$ に調節し，常温でそれぞれ $0.1 \mathrm{M}$ 硝酸銀で電位 差滴定したところ，Fig. 4 のような滴定曲線が得られ た.

すなわち，多量の亜硫酸イオンが共存する場合には， pH 5.3〜9.9 ではチオ硫酸イオンの終点を示さず， pH 3.5 付近になるとチオスルファート銀錯イオンの生成に 対応する電位变化が認められるようになる. これは $\mathrm{pH}$ 5.3 9.9 でも銀イオンとチオ硫酸イオンの錯生成は起 こるが，亚硫酸イオンとの反応も起こるため銀イオン濃 度が変化せず， $\mathrm{pH}$ が小さくなると亜硫酸銀の生成が少 なくなり，チオスルフォート銀鍇イオンの生成するとこ ろで銀イオン濃度が变化するためと考元られる。

以上の条件では硫化銀生成に対応する終点ははっきり

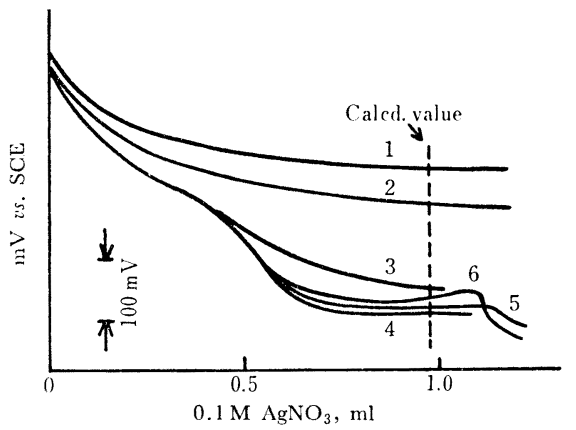

Fig. 4 Effect of $\mathrm{pH}$ on the titration curve for thiosulfate in the presence of a large amount of sulfite

$\left.\begin{array}{l}0.0005 \mathrm{M} \mathrm{Na}_{2} \mathrm{~S}_{2} \mathrm{O}_{3} \\ 0.1 \mathrm{M} \mathrm{Na} \mathrm{SO}_{3}\end{array}\right\} 100 \mathrm{ml} ; \quad \mathrm{pH}-1: 9.9,2: 7.4$, $3: 5.3,4: 3.5,5: 2.4,6: 1.8$

しないが，pH 2.4 付近になると硫化銀生成による電位 変化が認められるようになり，pH 1.8 で滴定した場合 にはこの電位変化が鋭く明確になった．終点はかなり大 きな正の誤差を伴うが，定量に必耍な条俳として，以下 pH 1.5 2.0 の範囲に 試料溶液を調節して 滴定与るこ とにする.

3.6.2 分析值に対する温度の影響 チオ硫酸イオン につき $0.0005 \mathrm{M}$ ，业硫酸イオンにつき $0.1 \mathrm{M}$ の混合溶 液 $100 \mathrm{ml}$ を加温器専用の滴定セルに入れ, 流動パラフ

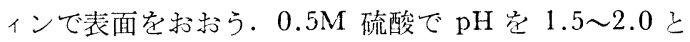
し, 約 2 分間以内で各温度に調節した後, それぞれ 0.1 $\mathrm{M}$ 硝酸銀で滴定した結果在 Fig. 5 に示す.

すなわち，200 倍モルの业硫酸イオンが其存する場合 には， $40^{\circ} \mathrm{C}$ 以下では正確な分析值が得られないが，被 滴定溶液の温度を（50〜65) ${ }^{\circ} \mathrm{C}$ にた場合には正確な分 析值を与えることが明らかになった。これは高温にする

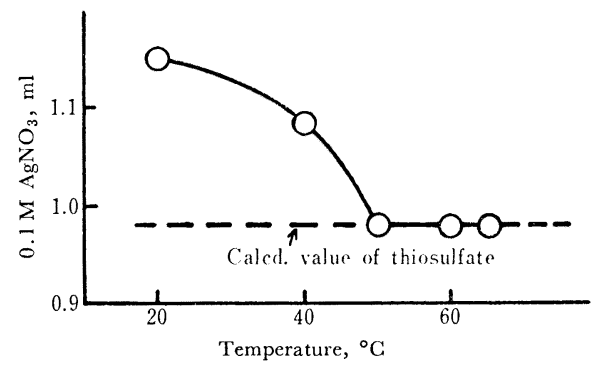

Fig. 5 Effect of temperature on the determination of thiosulfate in the presence of a large amount of sulfite $\left.\begin{array}{l}0.0005 \mathrm{M} \mathrm{Na}_{2} \mathrm{~S}_{2} \mathrm{O}_{3} \\ 0.1 \mathrm{M} \mathrm{Na}_{2} \mathrm{SO}_{3}\end{array}\right\} 100 \mathrm{ml} ; \quad \mathrm{pH} 1.5 \sim 2.0$ 
ことによって硫化銀の生成が促進されるためと考えられ る.

往って, 多量の画硫陵イオンが其存する場合には試料 溶液の $\mathrm{pH}$ を 1.5〜2.0, 温度を(50〜65) ${ }^{\circ} \mathrm{C}$ にしてチ オ硫酸イオンを滴定すればよいことになる.

\subsection{3 悪硫酸イオン共存量の分析値に対する影響}

(20４000）倍モルの亚硫酸ナトリウムと共存するチオ 硫酸イオン老 $\mathrm{pH} 1.5 \sim 2.0$, 温度 $(60 \sim 65)^{\circ} \mathrm{C}$ にして， (0.01〜0.1) M 硝酸銀で淌定した結果を Table 2 に示 于.

Table 2 Automatic titration of thiosulfate in the presence of sulfite

\begin{tabular}{ccccc}
\hline$\left[\mathrm{SO}_{3}{ }^{2-}\right] /\left[\mathrm{S}_{2} \mathrm{O}_{3}{ }^{2-}\right]$ & \multicolumn{2}{l}{ Concentration $(\mathrm{M})$} & $\begin{array}{c}\text { Relative } \\
\text { errort } \\
(\%)\end{array}$ & $\begin{array}{c}\text { Titration } \\
\text { time } \\
(\mathrm{min})\end{array}$ \\
\hline 20 & 0.0005 & 0.1 & +0.6 & 10 \\
50 & 0.0005 & 0.1 & +2.1 & 15 \\
250 & 0.0005 & 0.1 & +1.9 & 25 \\
500 & 0.0005 & 0.1 & +2.4 & 25 \\
1000 & 0.00005 & 0.01 & +1.8 & 30 \\
3000 & 0.00005 & 0.01 & $+2.1 \dagger \dagger$ & 30 \\
4000 & 0.00005 & 0.01 & +3.7 & 35 \\
\hline
\end{tabular}

Total volume : $100 \mathrm{ml} ; \quad \mathrm{pH}: 1.5 \sim 2.0 ; \quad$ Titration temp. : (60 $65)^{\circ} \mathrm{C}$; † Average of $(2 \sim 4)$ titrations; †† Coefficient of variation was $1.0 \%$.

共存量が多くなるに往って湳定時閒はやや長くなり， 正の誤差がわずかに大きくなるが，いずれの場合も定量 可能である. 3000 倍モルの韭硫酸ナトリウムが共存す る場合の滴定曲線は，Fig. 6 に示すように終点直前にお いて電位の乱れが認められるが終点は明確であった。

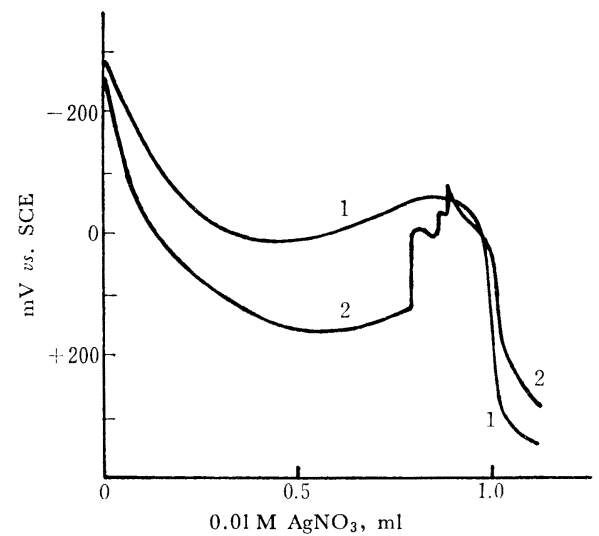

Fig. 6 Comparison of titration curves for thiosulfate in the absence and presence of sulfite 1: $0.00005 \mathrm{M} \mathrm{Na}_{2} \mathrm{~S}_{2} \mathrm{O}_{3}: 100 \mathrm{ml}$; $\left.2: \begin{array}{l}0.00005 \mathrm{M} \mathrm{Na}_{2} \mathrm{~S}_{2} \mathrm{O}_{3} \\ 0.15 \mathrm{M} \mathrm{Na}_{2} \mathrm{SO}_{3}\end{array}\right\} 100 \mathrm{ml}$ at $(60 \sim 65)^{\circ} \mathrm{C}$, pH 1.8
Table 3 Manual titration of thiosulfate in the presence of sulfite

\begin{tabular}{|c|c|c|c|c|}
\hline \multirow{2}{*}[\mathrm{SO}_{3}{}^{2-}]{$/\left[\mathrm{S}_{2} \mathrm{O}_{3}{ }^{2-}\right]$} & \multicolumn{2}{|c|}{ Concentration (M) } & \multirow{2}{*}{$\begin{array}{c}\text { Relative } \\
\text { errort } \\
(\%)\end{array}$} & \multirow{2}{*}{$\begin{array}{l}\text { Titration } \\
\text { time } \\
\text { (min) }\end{array}$} \\
\hline & $\mathrm{S}_{2} \mathrm{O}_{3}{ }^{2-}$ & $\mathrm{Ag}^{+}$ & & \\
\hline 200 & 0.0005 & 0.01 & +0.1 & 30 \\
\hline 2000 & 0.00005 & 0.01 & -0.3 & 40 \\
\hline 4000 & 0.00005 & 0.01 & $+0.6+\dagger$ & 50 \\
\hline
\end{tabular}

Total volume : $100 \mathrm{ml} ; \quad \mathrm{pH}: 1.5 \sim 2.0 ;$ Titration temp. : (60 $65)^{\circ} \mathrm{C} ; \quad+$ Average of $(2 \sim 4)$ titrations; †† Coefficient of variation was $0.3 \%$.

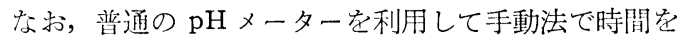
かけて \{電位の安定を待つため滴定時間 (30～50) 分間\} 滴定すると Table 3 のようになり，业硫酸ナトリウム 中の含有量として $0.025 \%$ 程度のチオ硫酸ナトリウム宏 $0.6 \%$ の相対䛊差で精度よく分析することができた。

$$
4 \text { 結 } \overrightarrow{\overline{\mathrm{i}}}
$$

硫化銀の生成を利用してチオ硫酸イオンを銀滴定する 方法に銀イオン選択電極を用いる電位差滴定法を適用 し，微量のチオ硫酸イオンを精度よく定量するための諸 条件を検討して次のような分析方法を確立した。

（i） チオ硫酸ナトリウム溶液の標定：(0.005～0.05) M チオ硫酸ナトリウム溶液 $10 \mathrm{ml}$ を滴定セルに分取し て水で $100 \mathrm{ml}$ とした後 $(\mathrm{pH} 1.5 \sim 10.5)$, 常温 $\left(20^{\circ} \mathrm{C}\right.$ 以上）で $0.1 \mathrm{M}$ 硝酸銀標準溶液で銀イオン選択電極と SCE を用いて電位差滴定を行う. 滴定所要時間（10〜 20）分の場合の滴定精度は $0.2 \%$ である.

(ii）亚硫酸ナトリウム中のチ才硫酸ナトリウムの定 量: チオ硫酸イオンにつき $0.00005 \mathrm{M}$ 溶液 $100 \mathrm{ml}(3000$ 倍モル程度の业硫酸イオンの共存可）の $\mathrm{pH}$ を 1.5 2.0 とした後, 加熱して約 $60^{\circ} \mathrm{G}$ とし， $0.01 \mathrm{M}$ 硝酸銀 標準溶液で 4(i) と同様に電位差滴定を行う. 滴定所要 時間（30４0）分の場合の滴定精度は約 $2 \%$ である。

$(1971$ 年 6 月 5 日，第 33 回分析) (化学討論会において一部発表)

\section{文献}

1) V. E. Müller : Z. Anorg. Allg. Chem., 134, 202 (1924).

2) R. E. Humphrey, R. M. Maniscalco, W. Hinze : Microchem. J., 16, 410 (1971).

3) E. Schmidt, E. Pungor : Anal. Lett., 4, 641 (1971).

4) J. Bodnar: Z. Anal. Chem., 53, 37 (1914).

5) S. Ikeda, H. Satake : Chem. Lett., 1972, 1191.

6) 池田早苗 : 本誌, 21, 177 (1972).

Potentiometric titration of thiosulfate ion with silver ion in the presence of sulfite. Sanae IKEDA and Hiromu SATAKE (Faculty of Engineering, 
Tokushima University, 2, Minamijosanjima-cho, Tokushima-shi, Tokushima)

A potentiometric titration of thiosulfate with silver ions was studied by using a silver ion selective electrode. The recommended procedure is as follows:

(1) Standardization of sodium thiosulfate solution Titrate $100 \mathrm{ml}$ of $(0.0005 \sim 0.005) \mathrm{M}$ thiosulfate solution ( $\mathrm{pH} 1.5 \sim 10.5$ ) with $0.1 \mathrm{M}$ silver nitrate solution at room temperature above $20^{\circ} \mathrm{C}$.

The relative error was $+0.2 \%$ and the coefficient of variation was less than $0.2 \%$ when the titration was carried out in $(10 \sim 20)$ minutes.

(2) Determination of sodium thiosulfate in sodium sulfite

Titrate $100 \mathrm{ml}$ of $(0.00005 \sim 0.0005) \mathrm{M}$ thiosulfate solution containing large amounts of sulfite with $(0.01$ 0.1) $\mathrm{M}$ silver nitrate solution. Before titration, adjust the solution $\mathrm{pH}$ to $1.5 \sim 2.0$ with dilute sulfuric acid and the solution temperature at about $60^{\circ} \mathrm{C}$.
A small amount of sodium thiosulfate (e.g. 0.025\%) was determined with the relative error of $+0.6 \%$ and the coefficient of variation of $0.3 \%$ when the titration was performed slowly in 50 minutes.

This titration method is simple and precise and especially suitable for the assay of a mixture of thiosulfate and sulfite.

(Received Nov. 7, 1975)

\section{Keywords}

Potentiometric titration

Silver ion selective electrode

Silver nitrate

Sulfite

Thiosulfate 